\title{
GROWTH AND ENERGY QUALITY OF EUCALYPTUS WOOD IN DIFFERENT CROP-LIVESTOCK-FOREST SPATIAL ARRANGEMENTS
}

\author{
Helio Tonini ${ }^{1}$, Marina Moura Morales ${ }^{2}$, Flavio Jesus Wruck ${ }^{3}$, Ronaldo Maran Deliberali ${ }^{4}$ \\ ${ }^{1}$ Embrapa Pecuária Sul, Bagé, Rio Grande do Sul, Brasil, helio.tonini@embrapa.br \\ ${ }^{2}$ Embrapa Florestas, Colombo, Paraná, Brasil, Marina.morales@embrapa.br \\ ${ }^{3}$ Embrapa Agrossilvipastoril, Sinop, Mato Grosso, Brasil. Flavio.wruck@embrapa.br \\ ${ }^{4}$ Engenheiro Florestal autônomo, Barra do Garças, Mato Grosso, Brasil. ronaldomaran@yahoo.com.br
}

Received for publication: 29/08/2018 - Accepted for publication: 30/05/2020

\begin{abstract}
Resumo
Crescimento e qualidade energética da madeira do eucalipto em diferentes arranjos de integração lavourapecuária-floresta. O objetivo do trabalho foi avaliar o crescimento e a qualidade energética da madeira de materiais genéticos de eucalipto em diferentes arranjos espaciais de plantio em sistema de integração lavourapecuária-floresta em Barra-do-Garças (MT). Foram avaliados cinco materiais genéticos de Eucalyptus spp em oito arranjos de plantio aos 76 meses de idade. As características avaliadas foram o crescimento em diâmetro, altura, volume, mortalidade, produção de massa seca, relação cerne e alburno, fator de forma, volume de casca, densidade básica, poder calorífico superior, teor de cinzas, voláteis, carbono fixo e energia no tronco. Os dados foram avaliados através do ajuste de uma função de crescimento, teste de identidade de modelos e ANOVA, com comparações de médias por Scott-Knott. Os clones de híbridos de Eucalyptus grandis x Eucalyptus urophylla apresentaram melhor desempenho para a produção de energia na região de Barra-do-Garça (MT), o que se deveu a maior produtividade volumétrica que foi determinante na estimativa de energia disponível por árvore e área plantada. O crescimento, a forma do tronco e a densidade básica variaram entre e dentro de um mesmo material genético em função do arranjo espacial de plantio. O mesmo não ocorreu com as propriedades energéticas da madeira como o poder calorífico superior, o teor de cinzas, carbono fixo e voláteis.

Palavras-chave: Curva de crescimento, densidade básica, poder calorífico, agrofloresta, Brasil.
\end{abstract}

\begin{abstract}
The aim of the present study was to assess the growth and energetic properties of genetic material of eucalyptus grown in several integrated crop-livestock system spatial arrangements in Barra-do-Garças City (MT). The genetic material of 76-month old Eucalyptus spp from eight spatial arrangements were assessed according to the following properties: diameter, height and volume growth, mortality rate, dry matter yield, sapwood to heartwood ratio, form factor, bark volume, basic density, superior calorific value, ash content, volatile matter, fixed carbon and trunk energy. Data analysis was performed by adjusting growth function, test for model identity and parameters equality and ANOVA tests to Scott-Knott's mean clustering test. Eucalyptus grandis $\mathrm{x}$ E. urophylla clones from recorded the highest energy efficiency due to their high yield volume, which was decisive to determine estimated energy available per tree and cropland area. Growth, stem shape and basic density varied among, and within, the same genetic materials, depending on their respective spatial arrangement. However, solid biomass properties (high calorific value, ash content, fixed carbon and volatile matter) remained stable.

Keywords: Growth curve, basic density, calorific value, agroforestry, Brazil.
\end{abstract}

\section{INTRODUCTION}

The afforestation of conventional cropland, known as integrated crop-livestock-forest systems (CLFS) or agroforestry systems, is one of the techniques embraced by the National Plan for Brazilian Low Carbon Emissions in Agriculture ( $\mathrm{ABC}$ Plan). These systems are part of the commitment to reduce greenhouse gas emissions assumed by Brazil at the 15th Conference of the Parties (COP 15) held in Copenhagen, back in 2009. The ABC Plan aims at reducing greenhouse gas emissions in agriculture, in order to improve natural resource management and adapt agriculture to climate change (MAPA 2018).

In recent years, there has been a considerable increase in the CLFS adoption in the country, totaling 11.5 million hectares, and Mato Grosso, with 1.5 million hectares, represents $13 \%$ of the national total (EMBRAPA 2018). However, in Mato Grosso, crop-livestock integration covers $89 \%$ of this area, with the forestcomponent being present in only $11 \%$ of the area occupied (GIL et al., 2015).

Yet, there are economic, technical and cultural barriers to the integration of trees into conventional agriculture. Forest integration requires a great deal of capital, time, labor, training and market knowledge. Moreover, it is a risky strategy that may trigger insecurity, as the integration of unsuitable tree species into cropping systems and/or spatial arrangements most likely lead to trading issues and to decreased crop yield (DIAS-FILHO; FERREIRA, 2008).

However, increasing the area planted with forest species in CLFS would be desirable due to the greater land use efficiency, environmental benefits provided by trees and mutual and complementary benefits, since

FLORESTA, Curitiba, PR, v. 50, n. 4, p. 1707 - 1716, out/dez 2020.

Tonini, H. et.al.

ISSN eletrônico 1982-4688

DOI: 10.5380/rf.v50 i4. 59650 
agriculture and livestock can cover the negative cash flow that occurs during the forest investment maturity period (PORFÍRIO-DA-SILVA, 2014)

Employment of biomass-energy alternatives to grain drying, slaughterhouses and ceramics industries in Mato Grosso State has increased firewood yield by $194 \%$ in the last ten years. As a result of it, eucalyptus plantations increased from 37.392 ha in 2006 to 212.815 ha in 2015, thus becomingthe forest genus with the largest planted area (FAMATO 2013).

Further scientific research is needed to help farmers from Mato Grosso State decide exactly what eucalyptus species or clones to plant, and how to plant them, for bioenergy production. Nevertheless, properties rather than growth and bioenergy production - such as basic density, calorific value, dry matter yield and biomass - should be assessed, as they can be altered by the genetic material, age, area and intercropping. Thus, The aim of the present study was to assess the growth and energetic properties of genetic material of eucalyptus grown in several integrated crop-livestock system designs in Barra-do-Garças City (MT)..

\section{MATERIALS AND METHODS}

Data was collected in the crop fields of Embrapa in partnership with Agropecuária Fazenda Brasil, in Barra-do-Garças City (MT), at coordinates $14^{\circ} 59^{\prime} 25.34^{\prime \prime S}$ and $52^{\circ} 16^{\prime} 21.05^{\prime \prime}$. The city is located in Southeastern Mato Grosso State (Figure 1), in a transition area between the Amazon and Cerrado biomes (MARACAHIPES et al., 2011). Tropical Savanna (Aw) is the local climate, with two well-defined seasons: dry (May to September) and rainy (October to April) (SOUZA et al., 2013).

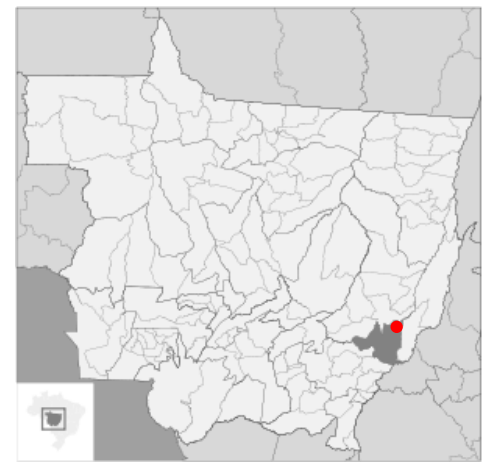

Figure 1. Geographic location of the state, city and study site.

Figura 1. Localização geográfica do estado, município e área de estudo.

Historically, total annual rainfall in Barra-do-Garças City ranged from 1200 to $2000 \mathrm{~mm}$ (SOUZA et al., 2013). Data from INMET (2018) indicated that it ranged from $958.2 \mathrm{~mm}$ to $1907.8 \mathrm{~mm}$ during the study's experiment; furthermore, 2013 and 2017 recorded the highest and lowest rainfall rates, respectively. The highest rainfall was recorded from October to March of 2018 (91.9\% of the total), with six dry months, which record rainfall lower than $60 \mathrm{~mm}$, on average. The predominant soil in the city is the Dystrophic Red-Yellow Latosol medium-textured, well drained and flat (MARACAHIPES et al., 2011).

The CLFS was established over a total area of 100 hectares in December 2010. However, the assessed systems evaluated totaled 49.6 hectares (Table 1). Soybean (Glycine max L.) crops were grown together with trees in the first five years; then, brachiaria grass (Brachiaria ruziziensis Satrf.) was introduced to the system.

Eucalyptus seedlings were planted after land demarcation, there was crop desiccation and post-emergent herbicide application to soybeans. Pre-sowing fertilization of forests species was performed by applying $70 \mathrm{~kg} \mathrm{ha}^{-}$ ${ }^{1}$ triple superphosphate (approximately $28 \mathrm{~kg} \mathrm{ha}^{-1} \mathrm{P}_{2} \mathrm{O}_{5}$ ) and $100 \mathrm{~g}_{\text {hole }}{ }^{-1} \mathrm{NPK}$ fertilizer (6:30:6) to each planting hole. Three months later, top-dressing was performed by manually applying 12:0:24 NPK added with 1.15\% Boron, at dose of $110 \mathrm{~g} \mathrm{plant}^{-1}$, to the crown cover area.

Five eucalyptus treatments were assessed: two Eucalyptus grandis x Eucalyptus urophylla clones (CL1 and CL2; trade names: H13 and GG100, respectively); two hybrids Eucalyptus urophylla x Eucalyptus camaldulensis (URC) and Eucalyptus grandis x Eucalyptus camaldulensis (GRC) and Eucalyptus camaldulensis (CAM), Acacia mangium (AMG) and Tectona grandis (TEC) from seedlings planted in eight spatial arrangements (Table 1). Test sample selection was based on tolerance to drought and on local nursery availability.

The spatial arrangements A5 to A8 grew mixed crops (Table 1): A5 consisted of Eucalyptus camaldulensis and Acacia mangium at 1:1 ratio (50\% eucalyptus and 50\% acacia); A6 and A8 had two Eucalyptus grandis x Eucalyptus urophylla clones (CL1 and CL2); A7 had CL1 and Tectona grandis (teak).

FLORESTA, Curitiba, PR, v. 50, n. 4, p. 1707 - 1716, out/dez 2020.

Tonini, H. et.al.

ISSN eletrônico 1982-4688

DOI: $10.5380 /$ rf.v50 i4. 59650 
Table 1. Species and spatial arrangements (SA) assessed at Fazenda Brasil in Barra-do Garças - MT. Tabela1. Espécies e arranjos espaciais implantados na Fazenda Brasil em Barra-do- Garças -MT

\begin{tabular}{ccccccccc}
\hline SA & $\begin{array}{c}\text { Cropland } \\
\text { (ha) }\end{array}$ & Species & $\begin{array}{c}\text { Number of } \\
\text { Rows }\end{array}$ & $\begin{array}{c}\text { Row } \\
\text { spacing } \\
(\mathrm{m})\end{array}$ & $\begin{array}{c}\text { Distances } \\
\text { in and } \\
\text { between } \\
\text { rows (m) }\end{array}$ & Trees (ha) & $\begin{array}{c}\text { Vital } \\
\text { Growth } \\
\text { space }\left(\mathrm{m}^{2}\right)\end{array}$ & $\begin{array}{c}\text { Area } \\
\text { ocuppied } \\
\text { per forest } \\
(\%)\end{array}$ \\
\hline A1 & 9.5 & CL1 & 3 & 23 & $3 \times 2$ & 517 & 19.4 & 27.6 \\
A2 & 12.3 & URC & 2 & 23 & $3 \times 2$ & 385 & 26.0 & 19.2 \\
A3 & 3.5 & GRC & 2 & 23 & $3 \times 2$ & 385 & 26.0 & 19.2 \\
A4 & 9.1 & CAM & 2 & 23 & $3 \times 2$ & 385 & 26.0 & 19.2 \\
A5 & 6.2 & CAM; & 3 & 23 & $3 \times 2$ & 517 & 19.4 & 27.6 \\
A6 & 3.0 & CL1; CL2 & 1 & 23 & $23 \times 2$ & 217 & 46.0 & 8.7 \\
A7 & 3.0 & CL1; TEC & 1 & 10 & $10 \times 2$ & 500 & 20.0 & 20.0 \\
A8 & 3.0 & CL1; CL2 & 1 & 8 & $8 \times 2$ & 625 & 16.0 & 25.0 \\
\hline
\end{tabular}

CL1, Eucalyptus grandis x Eucalyptus urophylla clones (trade name: H13); URC, Eucalyptus urophylla x Eucalyptus camaldulensis (hybrid); GRC, Eucalyptus grandis x Eucalyptus camaldulensis (hybrid); CAM, Eucalyptus camaldulensis; AMG, Acacia mangium; TEC, Tectona grandis; CL2, Eucalyptus grandis $\mathrm{x}$ urophylla clone (trade name: GG100)

Data on diameter at breast height $(\mathrm{DBH})$ growth $(\mathrm{cm})$, height $(\mathrm{m})$, individual volume $\left(\mathrm{m}^{3}\right)$ and mortality (\%) was collected from each arrangement. $\mathrm{DBH}$ and height growth data was collected from 18 permanent sample plots, in the center of two middle rows to avoid edge effects. The minimum number of 30 plants per sample was grown in spatial arrangements with plots ranging from 114 to $360 \mathrm{~m}^{2}$. Plots were measured four times: At 31, 51, 63 and 76-old months.

Individual volume, bark volume (\%), form factor, heartwood to sapwood ratio (H:S) and biomass properties were obtained from thirty trees; three of them were selected per arrangement and species. Trees in the middle rows were selected under the following criteria: quadratic mean DBH, good plant health status, good crown form and exposure to sunlight (North and South in A2, A3 and A4, North, South and central in A1 and A5).

Sample trees were felled at the age of 76 months. Mean individual trunk volume was calculated by the Smalian's formula. Tree mortality was obtained from counting failures and dead trees in all rows. Data was converted as follows:

$$
\operatorname{arcsen} \frac{\sqrt{x}}{100}
$$

Basic density $\left(\mathrm{g} / \mathrm{cm}^{-3}\right)$, heartwood and sapwood ratio $(\mathrm{H}: \mathrm{S})$ and bark volume percentage were determined from approximately $2.5 \mathrm{~cm}$-thick discs from cross-sections extracted at base, DBH and at 25\%, 50\%, 70\% and $90 \%$ of the total height. Basic density was determined through mean volume-weighted, based on Trugilho (2009), under standard NBR 11941-02. Calorific value was determined using a bomb calorimeter (standard NBR 8633/84); quick analysis was performed in muffle furnace (standard NBR 8112/83).

Heartwood:sapwood ratio was obtained by measuring four radii in each cross section with the aid of a millimeter-graded ruler, based on Pereira et al. (2013). Stem taper was calculated through artificial form factor and stem volume (\%), based on Finger (1992). The individual dry mass was obtained by multiplying the trunk volume by the basic density and the energy content per tree (KW.h), multiplying the dry mass by the superior calorific power, according to Santos et al. (2011).

Diameter and height growth curves were calculated using Chapman-Richards growth functions optimized by the Levenberg-Marquardt algorithm. Variables were expressed as follows:

$$
Y=A\left(1-\exp ^{(-k . T)}\right)^{R}
$$

Wherein: $\mathrm{Y}$, dependent variable (diameter at breast height in $\mathrm{cm}$, or total height in $\mathrm{m}$ ); A, asymptote; K, growth coefficient; R, shape coefficient; $\mathrm{T}$, age (in months).

Good fit was evaluated based on the coefficient of determination, standard error of estimates (\%) and residual standard error. Significance of estimated coefficients was tested through the asymptotic 95\% confidence interval. Coefficients were considered insignificant if the interval did not include zero.

After model fitting, the likelihood-ratio chi-squared test was performed to assess the equality of coefficients in growth curves (REGAZZI; SILVA, 2004). The hypotheses were:

$\mathrm{H}_{0}{ }^{(1)}=\mathrm{A}_{1}=\ldots \ldots \mathrm{A}_{\mathrm{g}}(=\mathrm{A})$ : not all $\mathrm{A}_{\mathrm{i}}$ are equal. 
$\mathrm{H}_{0}{ }^{(2)}=\mathrm{K}_{1}=\ldots . . . \mathrm{k}_{\mathrm{g}}(=\mathrm{k})$ : not all $\mathrm{k}_{\mathrm{i}}$ are equal.

$\mathrm{H}_{0}{ }^{(3)}=\mathrm{R}_{1}=\ldots \ldots \mathrm{R}_{\mathrm{g}}(=\mathrm{R})$; not all $\mathrm{R}_{\mathrm{i}}$ are equal.

$\mathrm{H}_{0}{ }^{(4)}=\mathrm{A}_{1}=\ldots \ldots \mathrm{A}_{\mathrm{g}}(=\mathrm{A})$ and $\mathrm{R}_{1}=\ldots \ldots \mathrm{R}_{\mathrm{g}}(=\mathrm{R})$

$\mathrm{H}_{0}{ }^{(5)}=\mathrm{A}_{1}=\ldots \ldots \mathrm{A}_{\mathrm{g}}(=\mathrm{A}) ; \mathrm{K}_{1}=\ldots \ldots . \mathrm{k}_{\mathrm{g}}(=\mathrm{k})$ and $\mathrm{R}_{1}=\ldots \ldots \mathrm{R}_{\mathrm{g}}(=\mathrm{R})$ : at least one equality is false.

The decision rule for this test is that $\mathrm{H}_{0}$ at $1 \%$ significance level should be rejected if $x^{2}$ calculated $\geq x^{2}(v)$, wherein $v=$ degrees of freedom $\left(\rho_{\Omega}-\rho_{\omega}\right)$

$$
\chi_{\text {calculated }}^{2}=-N \cdot N l\left(\frac{S S R^{\prime} \Omega}{R S S \omega}\right)
$$

Wherein: N, number of observations; Nl, Neperian logarithm; $\mathrm{SSR}_{\Omega}$, total sum of squares; $\mathrm{RSS}_{\omega}$, residual sum of squares; $\rho_{\Omega}$ , number of estimated parameters in the full model; $\rho_{\omega}$, number of estimated parameters in the reduced model.

The resulting dataset was subjected to Kolmogorov-Smirnov Test for Normality and Levene's Homogeneity of Variance Test. Correlations among genetic materials and spatial arrangements were calculated by the growth curve model and by ANOVA, based on a completely randomized design applied to ten treatments (eucalyptus genetic materials and spatial arrangements), with three replications (trees). Means among treatments were compared through Scott-Knott's test, and means among controls (clones x hybrids) were compared through t-test,both at $95 \%$ confidence interval.

\section{RESULTS}

A common equation could not fit the CAM species' DHB data, since $\mathrm{H}_{0}{ }^{5}$ should not be accepted (Table 2 and Figure $2 \mathrm{~A}$ ) with restriction in the parametric space for all parameters of the model. $\mathrm{H}_{0}{ }^{5}$ was not significant for height growth, thus it was calculated through a common equation (Table 2 and Figure $2 \mathrm{~B}$ ). $\mathrm{H}_{0}{ }^{5}$ was rejected for both variables of CL2, thus it proved the effect of spatial arrangements on diameter at breast height (DHB) growth and height (Table 2), as shown by the growth curve model (Figures 2C and 2D).

DBH growth curves between CL1's A6 and A7 was not significant according to $\mathrm{H}_{0}{ }^{5}$ and data of A1, A6 and $\mathrm{A} 7$ can be grouped for height comparison purposes. $\mathrm{H}_{0}{ }^{4}$ indicated that $\mathrm{A} 8$ differed from the others and had parametric space for equality between parameters $\mathrm{A}$ and $\mathrm{R}$ restricted. Identifiability analysis results were graphically portrayed through the growth curve model (Figures $2 \mathrm{E}$ and $2 \mathrm{~F}$ ).

Table 2. Likelihood-ratio chi-squared test $\left(\boldsymbol{x}^{2}\right)$ performed to assess coefficient equality between diameter (DBH) and height $(\mathrm{H})$.

Tabela 2. Teste de razão de verossimilhança com aproximação pelo qui-quadrado $\left(\varkappa^{2}\right)$ para avaliar a identidade de parâmetros para diâmetro (DAP) e altura (H).

\begin{tabular}{|c|c|c|c|c|c|c|c|c|c|c|c|}
\hline \multirow{3}{*}{$\begin{array}{l}\text { Genetic } \\
\text { material }\end{array}$} & \multirow{3}{*}{$\begin{array}{c}\text { Compared } \\
\text { SA }\end{array}$} & \multicolumn{5}{|c|}{ DBH } & \multicolumn{5}{|c|}{ Height } \\
\hline & & \multicolumn{10}{|c|}{ Hypotheses } \\
\hline & & $\mathrm{H}_{0}{ }^{(1)}$ & $\mathrm{H}_{0}^{(2)}$ & $\mathrm{H}_{0}{ }^{(3)}$ & $\mathrm{H}_{0}{ }^{(4)}$ & $\mathrm{H}_{0}{ }^{(5)}$ & $\mathrm{H}_{0}{ }^{(1)}$ & $\mathrm{H}_{0}^{(2)}$ & $\mathrm{H}_{0}{ }^{(3)}$ & $\mathrm{H}_{0}^{(4)}$ & $\mathrm{H}_{0}{ }^{(5)}$ \\
\hline CAM & $4-5$ & $14.7^{*}$ & $14.6^{*}$ & $2.9^{*}$ & $14.3^{*}$ & $132.9^{*}$ & 0.3 & 0.4 & 0.1 & 0.3 & 8.5 \\
\hline \multirow[t]{3}{*}{ CL2 } & $6-8$ & $26.2^{*}$ & $26.1^{*}$ & 3.5 & $198.4^{*}$ & $424.3^{*}$ & $117.9^{*}$ & $114.6^{*}$ & $16.2^{*}$ & $31.9^{*}$ & $114.7^{*}$ \\
\hline & $1-6$ & 10.4 & 10.3 & $61.8^{*}$ & 3.81 & $359.8^{*}$ & 0.1 & 0.1 & 0.2 & 2.8 & 7.60 \\
\hline & $1-7$ & 10.5 & 10.5 & 10.4 & $16.4^{*}$ & $311.4^{*}$ & 2.1 & 1.9 & 1.9 & 2.17 & 9.6 \\
\hline \multirow[t]{4}{*}{ CL1 } & $1-8$ & $209.5^{*}$ & $209.4^{*}$ & $208.9^{*}$ & $208.6^{*}$ & $81.3^{*}$ & 0.6 & 4.3 & 8.7 & $52.2^{*}$ & $363.0^{*}$ \\
\hline & $6-7$ & 1.1 & 0.5 & 0.3 & 6.8 & 8.9 & 5.1 & 5.1 & 5.4 & 11.8 & 13.5 \\
\hline & $6-8$ & $222.3^{*}$ & $221.3^{*}$ & $219.0^{*}$ & $206.5^{*}$ & $39.7^{*}$ & 13.4 & 6.6 & 12.1 & $82.3^{*}$ & $259.1^{*}$ \\
\hline & $7-8$ & $245.3^{*}$ & $243.4^{*}$ & $240.5^{*}$ & $226.0^{*}$ & $193.4^{*}$ & 2.0 & 2.6 & 5.4 & $21.3^{*}$ & $102.8^{*}$ \\
\hline
\end{tabular}

CAM, Eucalyptus camaldulensis; CL1, Eucalyptus grandis x Eucalyptus urophylla clone (trade name: H13); CL2, Eucalyptus urophylla clone (trade name: GG100). *significant at 5\% confidence level. SA, spatial arrangments 

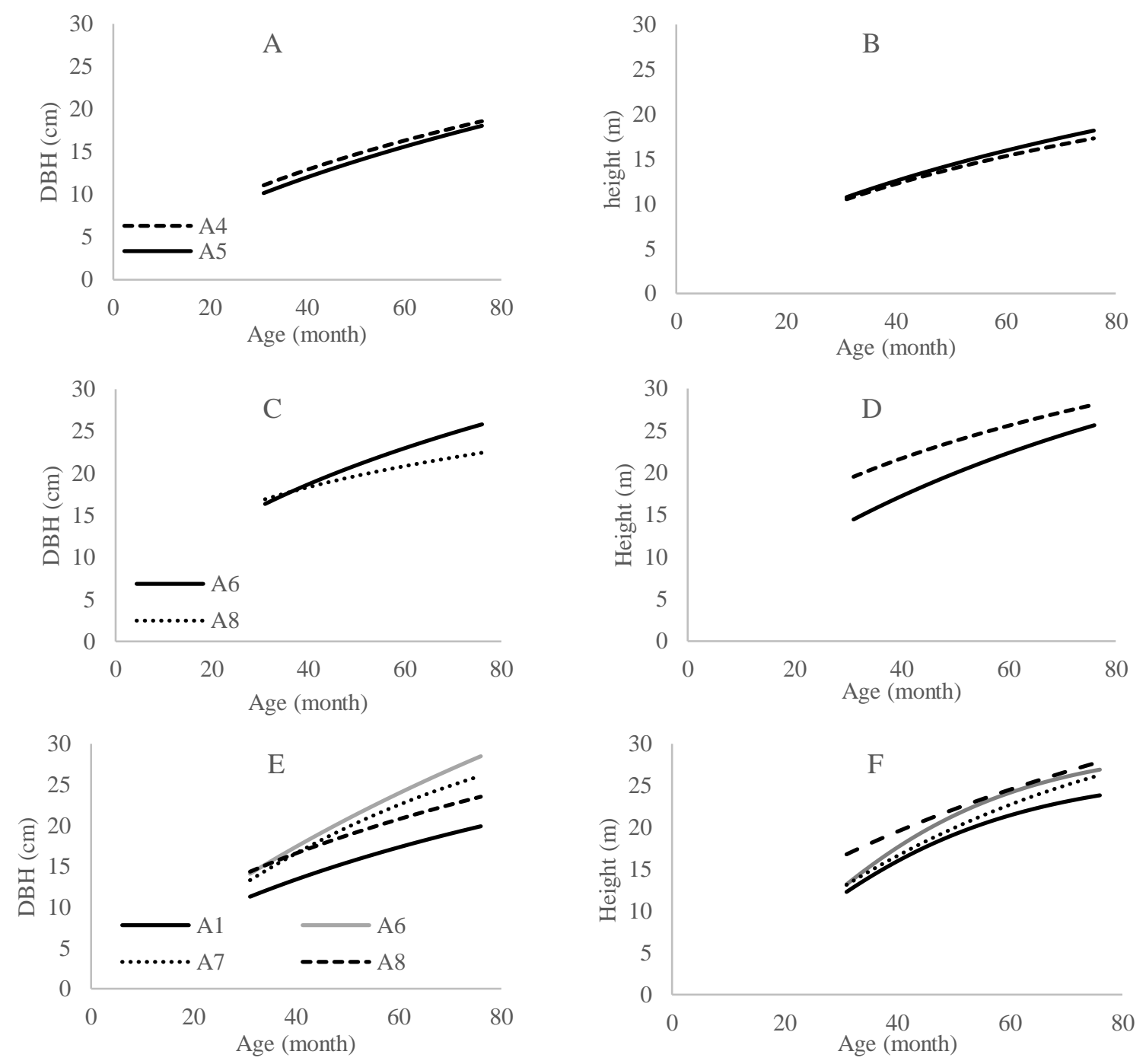

Figure 2. Growth curve of diameter at breast height (DBH) and height of Eucalyptus camaldulensis (A and B), clone $2(\mathrm{C}$ and $\mathrm{D})$ and clone $1(\mathrm{E}$ and $\mathrm{F})$.

Figura 2. Curva de crescimento para diâmetro a altura do peito (DAP) e altura para Eucalyptus camadulensis (A e B), clone 2 (C e D) e clone 1 (E e F).

Identity test analysis provided equations and estimated parameters for all the assessed genetic materials and spatial arrangements (Table and Figure 3). Statistical adjustment for $\mathrm{R}^{2}$ and Syx $\%$ ranged from 0.30 to 0.77 and from $10.5 \%$ to $27.4 \%$ for $\mathrm{DBH}$, and from 0.28 to 0.81 and $9.8 \%$ to $22.6 \%$ for height. All coefficients were significant at $5 \%$ level and clones presented better fit statistics. 
Table 3. Coefficients and fit statistics of Chapman-Richards function by species and spatial arrangement. Tabela 3. Parâmetros estimados e estatísticas de ajuste da função de Chapman-Richards por espécie e arranjo

\begin{tabular}{|c|c|c|c|c|c|c|c|c|c|c|c|}
\hline \multicolumn{7}{|c|}{$\mathrm{DBH}(\mathrm{cm})$} & \multicolumn{5}{|c|}{ Height (m) } \\
\hline \multirow{2}{*}{$\begin{array}{c}\text { Spatial } \\
\text { Arrangements }\end{array}$} & \multirow[b]{2}{*}{ Species } & \multicolumn{3}{|c|}{ Coefficient } & \multicolumn{2}{|c|}{ Fit } & \multicolumn{3}{|c|}{ Coefficient } & \multicolumn{2}{|c|}{ Fit } \\
\hline & & $\mathrm{A}$ & $\mathrm{K}$ & $\mathrm{R}$ & $\mathrm{R}^{2}$ & Syx\% & $\bar{A}$ & $\mathrm{~K}$ & $\mathrm{R}$ & $\overline{\mathrm{R}^{2}}$ & Syx\% \\
\hline 1 & CL1 & 36.710 & 0.008 & 0.779 & 0.47 & 20.82 & 26.785 & 0.039 & 2.199 & 0.78 & 12.07 \\
\hline 2 & URC & 50.300 & 0.004 & 0.664 & 0.36 & 25.93 & 44.120 & 0.007 & 0.771 & 0.28 & 21.47 \\
\hline 3 & GRC & 52.520 & 0.004 & 0.698 & 0.34 & 26.06 & 63.266 & 0.002 & 0.528 & 0.29 & 22.64 \\
\hline 4 & CAM & 38.820 & 0.005 & 0.668 & 0.36 & 24.74 & -- & -- & -- & -- & -- \\
\hline 5 & CAM & 54.339 & 0.003 & 0.698 & 0.30 & 27.43 & 32.873 & 0.007 & 0.680 & 0.54 & 16.89 \\
\hline 6 e 7 & CL1 & 43.361 & 0.013 & 1.082 & 0.77 & 12.0 & -- & -- & -- & -- & -- \\
\hline 1,6 e 7 & CL1 & -- & -- & -- & -- & -- & 28.87 & 0.034 & 1.944 & 0.81 & 10.81 \\
\hline 6 & CL2 & 54.94 & 0.004 & 0.564 & 0.68 & 11.08 & 43.325 & 0.010 & 0.829 & 0.81 & 9.81 \\
\hline 8 & CL1 & 48.41 & 0.005 & 0.642 & 0.55 & 15.47 & 62.840 & 0.003 & 0.600 & 0.63 & 12.67 \\
\hline 8 & CL2 & 43.000 & 0.002 & 0.332 & 0.34 & 10.55 & 56.390 & 0.003 & 0.438 & 0.56 & 10.31 \\
\hline
\end{tabular}

CL1 , Eucalyptus grandis x Eucalyptus urophylla clone (trade name: H13); URC, Eucalyptus urophylla x Eucalyptus camaldulensis (hybrid); GRC, Eucalyptus grandis x Eucalyptus camaldulensis (hybrid); CAM, Eucalyptus camaldulensis; CL2, Eucalyptus urophylla clone (trade name: GG100).
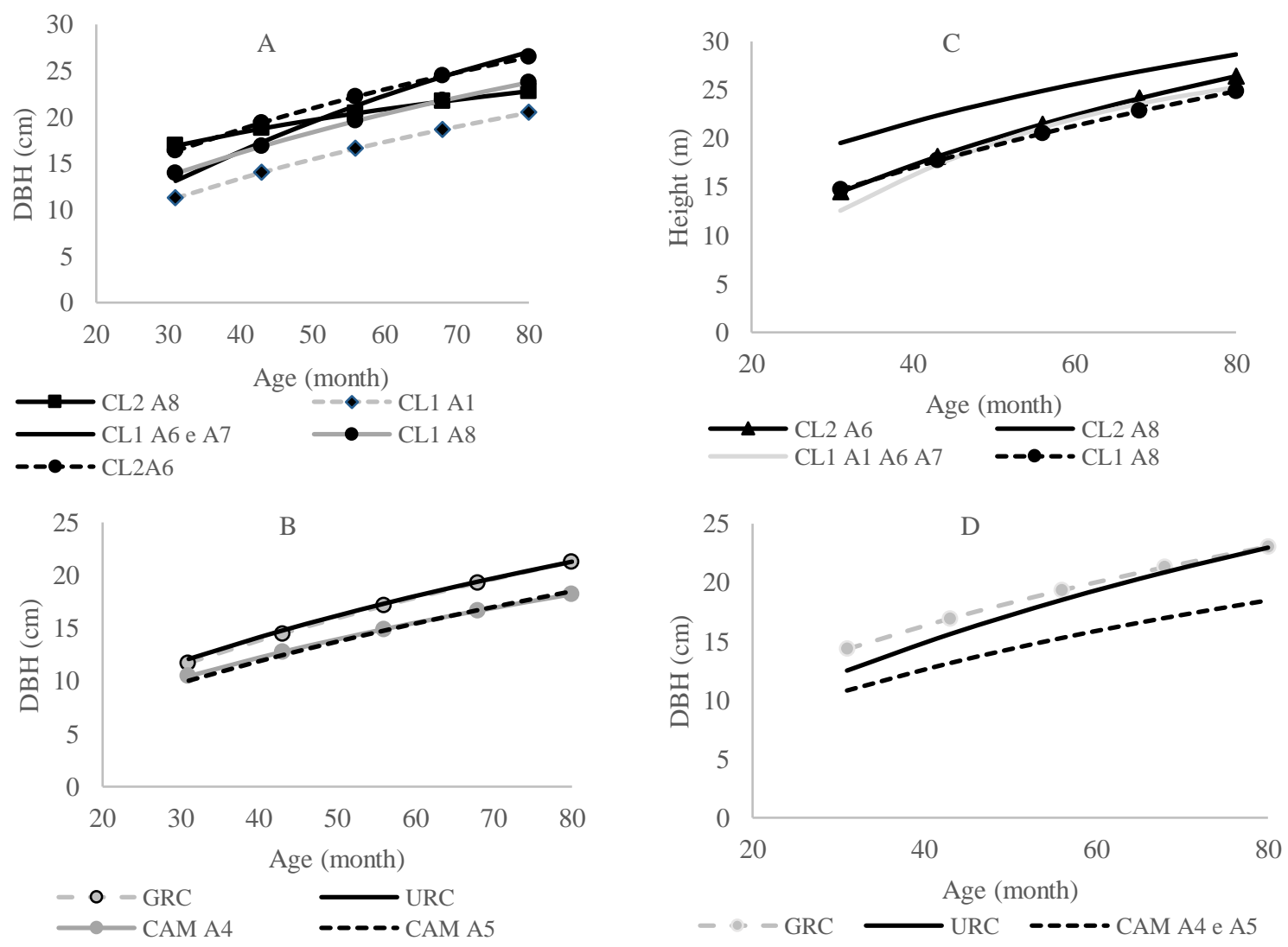

Figure 3. Diameter growth curve (A and B) and total height (C and D) of eucalyptus in spatial arrangements set in Barra do Garças City (MT).

Figura 3. Curva de crescimento em diâmetro (A e B) e altura total (C e D) para eucalipto nos arranjos espaciais em Barra-do-Garças (MT). 
Mean annual increment in diameter ranged from 2.8 to $4.3 \mathrm{~cm}$ at 76-month old trees; CL1 and CL2 (A6 and A7) had the highest rates (Table 4 and Figure 3A), whereas CAM (A4 and A5) had the lowest ones (Table 4 and Figure 3 B). Mean annual increment in total height ranged from 2.6 to $4.3 \mathrm{~m}$; CL1 and CL2 (A6, A7 and A8) had the highest rates, whereas CAM (A4 and A5) had the lowest ones (Table 4 and Figures 3 C and D).

Total individual volume and form factor have varied depending on the genetic material and on the spatial arrangements (Table 4). Individual volume ranged from 0.220 to $0.565 \mathrm{~m}^{3}$; CL1 and CL2 (A6 and A7) presented the highest rates, whereas CAM (A4 and A5) presented the lowest ones. Form factor ranged from 0.35 to 0.49 in the two groups: (I) GRC, CL1 and CL2 in A3, A6 and A8 (0.35 to 0.39, 0.37, on average); (II) CL1, URC and CAM in A1, A2, A4, A5, A7 and A8 (0.41 to $0.49,0.44$, on average).

Bark volume ranged from 9.94\% to 18.07\%; CAM in A5 recorded the highest bark volume (\%) (Table 4). CL1 and CL2 in A6, A7 and A8 presented higher dry matter yield per tree. Heartwood:sapwood (H:S) ratio ranged from 0.25 to 0.89 ; CL1 and CL2 in A8 recorded the highest H:S ratio. CL2 recorded lower mean mortality rate $(8.5 \%)$. CAM reported the lowest mortality rate (12.7\%) among seedlings, whereas URC had the highest one $(49.7 \%)$.

Table 4. Dendrometry of genetic material from 76-month old eucalyptus and spatial arrangements in intercrops in Barra-do-Garças (MT).

Tabela 4. Variáveis dendrometricas avaliadas para os arranjos e materiais de eucalipto testados em Barra-doGarças (MT) aos 76 meses.

\begin{tabular}{|c|c|c|c|c|c|c|c|c|c|c|c|}
\hline $\begin{array}{c}\text { Spatial } \\
\text { Arrangement }\end{array}$ & Species & $\begin{array}{l}\begin{array}{c}\text { DBH } \\
(\mathrm{cm})\end{array} \\
\end{array}$ & $\begin{array}{l}\mathrm{CV} \% \\
\mathrm{DBH}\end{array}$ & $\begin{array}{l}\text { Height } \\
(\mathrm{m})\end{array}$ & $\begin{array}{l}\text { CV\% } \\
\text { height }\end{array}$ & $\mathrm{V}\left(\mathrm{m}^{3}\right)$ & $\begin{array}{l}\mathrm{DM} \\
(\mathrm{kg})\end{array}$ & M\% & $\mathrm{F}_{1,30}$ & $\mathrm{Bv} \%$ & $\mathrm{H}: \mathrm{S}$ \\
\hline 1 & CL1 & $19.3^{\mathrm{d}}$ & 21.9 & $23.6^{\mathrm{b}}$ & 12.1 & $0.344^{\mathrm{c}}$ & $0.163^{\mathrm{b}}$ & $27.2^{\mathrm{b}}$ & $0.44^{\mathrm{a}}$ & $11.64^{\mathrm{c}}$ & $0.37^{\mathrm{b}}$ \\
\hline 2 & URC & $21.8^{\mathrm{c}}$ & 25.4 & $22.7^{\mathrm{b}}$ & 14.2 & $0.396^{c}$ & $0.214^{\mathrm{a}}$ & $39.7^{\mathrm{a}}$ & $0.43^{\mathrm{a}}$ & $13.34^{\mathrm{c}}$ & $0.43^{\mathrm{b}}$ \\
\hline 3 & GRC & $20.7^{c}$ & 22.6 & $20.2^{c}$ & 19.4 & $0.308^{c}$ & $0.152^{\mathrm{b}}$ & $49.7^{\mathrm{a}}$ & $0.37^{b}$ & $10.20^{\mathrm{c}}$ & $0.25^{\mathrm{b}}$ \\
\hline 4 & CAM & $17.7^{\mathrm{e}}$ & 25.1 & $17.4^{\mathrm{d}}$ & 23.3 & $0.221^{\mathrm{d}}$ & $0.135^{\mathrm{b}}$ & $12.7^{\mathrm{c}}$ & $0.44^{\mathrm{a}}$ & $14.95^{\mathrm{b}}$ & $0.30^{\mathrm{b}}$ \\
\hline 5 & CAM & $17.4^{\mathrm{e}}$ & 25.4 & $16.9^{\mathrm{d}}$ & 18.5 & $0.220^{\mathrm{d}}$ & $0.125^{\mathrm{b}}$ & $15.9^{\mathrm{c}}$ & $0.44^{\mathrm{a}}$ & $18.07^{\mathrm{a}}$ & $0.46^{\mathrm{b}}$ \\
\hline 6 & CL1 & $27.3^{\mathrm{a}}$ & 8.8 & $23.9^{\mathrm{b}}$ & 5.7 & $0.523^{\mathrm{a}}$ & $0.267^{\mathrm{a}}$ & $53.0^{\mathrm{a}}$ & $0.37^{b}$ & $14.24^{\mathrm{b}}$ & $0.40^{\mathrm{b}}$ \\
\hline 6 & CL2 & $26.2^{\mathrm{a}}$ & 10.3 & $26.1^{\mathrm{a}}$ & 9.4 & $0.524^{\mathrm{a}}$ & $0.257^{\mathrm{a}}$ & $12.7^{\mathrm{c}}$ & $0.35^{\mathrm{b}}$ & $10.43^{c}$ & $0.52^{\mathrm{b}}$ \\
\hline 7 & CL1 & $25.8^{\mathrm{a}}$ & 12.8 & $26.3^{\mathrm{a}}$ & 9.5 & $0.565^{\mathrm{a}}$ & $0.303^{\mathrm{a}}$ & $49.2^{\mathrm{a}}$ & $0.41^{\mathrm{a}}$ & $13.02^{\mathrm{c}}$ & $0.59^{\mathrm{b}}$ \\
\hline 8 & CL1 & $23.3^{\mathrm{b}}$ & 13.3 & $26.5^{\mathrm{a}}$ & 13.2 & $0.460^{\mathrm{b}}$ & $0.235^{\mathrm{a}}$ & $43.3^{\mathrm{a}}$ & $0.49^{\mathrm{a}}$ & $12.18^{\mathrm{c}}$ & $0.89^{\mathrm{a}}$ \\
\hline 8 & CL2 & $21.7^{\mathrm{c}}$ & 9.3 & $27.2^{\mathrm{a}}$ & 7.3 & $0.361^{\mathrm{c}}$ & $0.137^{\mathrm{b}}$ & $4.30^{\mathrm{d}}$ & $0.39^{b}$ & $9.94^{\mathrm{c}}$ & $0.86^{\mathrm{a}}$ \\
\hline
\end{tabular}

CL1, Eucalyptus grandis x Eucalyptus urophylla clone (trade name: H13); URC, Eucalyptus urophylla x Eucalyptus camaldulensis (hybrid); GRC, Eucalyptus grandis x Eucalyptus camaldulensis (hybrid); CAM, Eucalyptus camaldulensis; CL2, Eucalyptus urophylla clone (trade name: GG100); v $=$ total volume $\left(\mathrm{m}^{3} ; \mathrm{M} \%=\right.$ mortality rate; $\mathrm{F}_{1,30}=$ artificial form factor; $\mathrm{Bv}=$ bark volume; Sap = sapwood area. DM, Dry matter $(\mathrm{kg}) ; . \mathrm{M}$, mortality, $\mathrm{F} 1,30$ form factor, $\mathrm{Bv}$, bark volume, $\mathrm{H}: \mathrm{S}$, heartwood and sapwood relationshipMeans with the same letter were not significantly different at 0.05 probability level in the Scott-Knott's test.

Superior calorific value, volatile matter and fixed carbon recorded means of $4145.3 \mathrm{kcal} / \mathrm{kg}^{-1}, 80.18 \%$ and $18.97 \%$, respectively, with no statistical difference (Table 5). Basic density ranged from 0.47 to $0.61 \mathrm{~g} \mathrm{~cm}^{-3}$ : the highest mean for CAM in A4 and the lowest ones for CL1 and CL2 in A1 and A6, respectively. CL1 in A7 presented the highest stemwood biomass. 
Table 5. Wood quality for energy purposes of the eucalyptus spatial arrangements and materials tested in Barra do Garças (MT) at 76 months.

Tabela 5. Qualidade da madeira para fins energéticos dos arranjos e materiais de eucalipto testados em Barra do Garças (MT) aos 76 meses

\begin{tabular}{|c|c|c|c|c|c|c|c|}
\hline Arrangement & Species & $\begin{array}{c}\mathrm{SCV} \\
\left(\mathrm{kcal} / \mathrm{kg}^{-1}\right)\end{array}$ & Ash (\%) & $\begin{array}{c}\text { Volatile } \\
\text { matter }(\%)\end{array}$ & $\begin{array}{c}\text { Fcarbon } \\
(\%)\end{array}$ & $\begin{array}{c}\mathrm{B}_{\mathrm{d}} \\
\left(\mathrm{g} / \mathrm{cm}^{-3}\right)\end{array}$ & $\begin{array}{c}\text { Stem energy } \\
\text { biomass } \\
\left(\mathrm{kWh}^{-1}\right)\end{array}$ \\
\hline 1 & CL1 & 4150 & 0.53 & 81.0 & 18.4 & $0.47^{\mathrm{d}}$ & $0.786^{\mathrm{e}}$ \\
\hline 2 & URC & 4163 & 0.38 & 80.5 & 19.2 & $0.54^{\mathrm{c}}$ & $1.035^{\mathrm{c}}$ \\
\hline 3 & GRC & 4162 & 0.47 & 81.6 & 18.0 & $0.49^{c}$ & $0.476^{\mathrm{e}}$ \\
\hline 4 & CAM & 4093 & 1.16 & 79.3 & 19.5 & $0.61^{\mathrm{a}}$ & $0.639^{f}$ \\
\hline 5 & CAM & 4099 & 1.28 & 77.3 & 21.4 & $0.57^{b}$ & $0.594^{\mathrm{f}}$ \\
\hline 6 & CL1 & 4135 & 0.67 & 78.9 & 20.4 & $0.51^{\mathrm{c}}$ & $1.280^{\mathrm{b}}$ \\
\hline 6 & CL2 & 4166 & 0.82 & 80.8 & 17.5 & $0.49^{\mathrm{d}}$ & $1.246^{\mathrm{b}}$ \\
\hline 7 & CL1 & 4157 & 0.67 & 80.1 & 19.2 & $0.53^{c}$ & $1.460^{\mathrm{a}}$ \\
\hline 8 & CL1 & 4115 & 0.66 & 80.7 & 18.6 & $0.51^{\mathrm{c}}$ & $1.131^{\mathrm{c}}$ \\
\hline 8 & CL2 & 4213 & 0.52 & 81.6 & 17.5 & $0.51^{\mathrm{c}}$ & $0.928^{d}$ \\
\hline
\end{tabular}

CL1,Eucalyptus grandis x Eucalyptus urophylla clone (trade name: H13); URC,Eucalyptus urophylla x Eucalyptus camaldulensis (hybrid); GRC, Eucalyptus grandis x Eucalyptus camaldulensis (hybrid); CAM,Eucalyptus camaldulensis; CL2,Eucalyptus urophylla clone (trade name: GG100); SCV, superior calorific value; Fcarbon = fixed carbon; $\mathrm{B}_{\mathrm{d}}=$ basic density.

\section{DISCUSSION}

Overall, clones grown in large vital growth space recorded the highest rates of individual volume and diameter growth. CL1 (A6 and A7) and CL2 (teak) recorded similar rates due to CL1's little competition for sunlight against the slow-growing teak (CL2), as identified by the growth curve model (Table 3) and by ANOVA (Table 5). Height difference between 76-months old CL1 and CL2 was $11.6 \mathrm{~m}$.

There was no statistical difference between the survival rates of clones and seedling materials $\left(\mathrm{T}_{(8)}=0.17 ; \mathrm{p}=\right.$ $0.43)$. Therefore, the high efficiency rate of cloned plants can be associated with high growth and trees homogeneity rates, since these plants recorded the lowest diameter and height coefficients of variation at the age of 76 months $(24.08 \%$ and $17.5 \%$ for seedlings; $10.9 \%$ and $9.02 \%$ for clones, respectively).

Mean mortality rate (30.8\%) and its variance (4.3 to 53\%) were higher than those of studies by Franchini et al. (2014) and Nieri et al. (2018), who found rates ranging from 0 to $23 \%$ in different Eucalyptus and Corymbia plant species grown in crop-livestock-forest systems. This variable proves the establishment potential / adaptability of plants to the current ecological status of croplands (MACEDO et al., 2010), mainly, to limited climatic conditions, such as low humidity and 6 month long dry seasons observed in this region

Spatial arrangements had little effect on plant height growth, as no significant difference was detected through the following analyses: Growth curve of CL1 among A1, A6 and A7 (Table 2 and Figure 3C); ANOVA of CL1 and CL2 among A6, A7 and A8. Therefore, the gains in volumetric increase were due to the greater expansion in basal area in the spatial arrangements with the largest growth vital space available to plants..

The aforementioned effect was highlighted by CL1 in spatial arrangements 1 to 8: A1 presented lower initial density and smaller lgrowth vital space than A8 (Table 1); it also grew thinner, presented lower trees, with lower individual volume and dry matter. This finding corroborates the study by Henskens et al. (2001), who found that volume and yield are directly affected by density and tree spatial patterns. The authors have demonstrated that isolated trees are more efficient in converting sunlight into biomass through photosynthesis, because of their large leaf area, intercepts more radiant energy.

CAM wood growth and properties (except for basic density) were not affected by the spatial arrangements. This finding suggests that there was little competition between CAM and Acacia mangium. Accordingly, Oliveira et al. (2015) found that $A$. mangium is oftentimes quickly suppressed by Eucalyptus when these species are grown together.

CAM (18.07\%) and CL1, in A6, have recorded higher bark volume (\%), which varied among spatial arrangements. High bark volume (\%) is unsuitable for bioenergy and coal generation, since its mineral content can generate greater amounts of ash in the burning process. This ash is corrosive and accumulates in the furnace, thus, it forces intermittent pauses during the process for machine cleaning (ANDRADE et al., 2013).

Basic density ( 0.47 to $0.61 \mathrm{~g} / \mathrm{cm}^{-3}$ ) recorded values below those recommended for direct burning (VALE et al., 2002). Authors suggest that the ideal mean ratio between semi-hardwood and hardwood must range from 0.65 to $0.80 \mathrm{~g} / \mathrm{cm}^{-3}$. Basic density varied among different species and within the same species in plant spatial arrangements

For CL1 and CL2, the increase in the number of trees per unit area and the reduction of growth vital space reduced the diameter growth and basic density. This finding corroborates studies by Sereghetti et al. (2015) and Rocha et al. (2016), who found low basic density in small spacings of Eucalyptus grandis x Eucalyptus urophylla and Eucalyptus grandis x Eucalyptus camaldulensis clones, respectively. For CAM, there was no statistically significant

FLORESTA, Curitiba, PR, v. 50, n. 4, p. 1707 - 1716, out/dez 2020.

Tonini, H. et.al.

ISSN eletrônico 1982-4688

DOI: $10.5380 /$ rf.v50 i4. 59650 
difference for the mean diameter at 76 months between the two planting spatial arrangements (Table 3), but diameter growth curve showed superiority in A4 (Table 2 and Figure 2) and, in this spatial arrangement, the basic density was higher

Heartwood to sapwood ratio can affect basic density and wood drying, thus it affects charcoal production (PEREIRA et al., 2013). Authors suggest that high heartwood content can complicate wood drying due to the high impermeability of wood. Therefore, wood with genetically low $\mathrm{H}: \mathrm{S}$ ratio is the most suitable for energy generation. The assessed H:S ratio varied according to the genetic material and spatial planting arrangements, since CL1 and CL2, in A8, recorded the highest initial planting density and the highest H:S ratio in the smallest growth vital space. However, no direct correlation was found between $\mathrm{H}: \mathrm{S}$ ratio and basic density.

CAM in A4 recorded individual dry matter equal to that of A5, despite their high-density wood and the lowest individual volumetric production caused the lowest dry weight production per tree $(0.130 \mathrm{~kg}$ tree-1). CL1, CL2 and URC in spatial arrangements $2,6,7$ and 8 recorded the highest mean dry matter yield per tree $\left(0.255 \mathrm{~kg}\right.$ tree $\left.^{-1}\right)$. which highlights the importance of volumetric productivity on the estimates of biomass and wood available energy (SANTOS et al., 2011).

The wood mass quantification was directly related to the trunk available energy. CL1 and CL2 in A6 and A7 were superior in the energy stored in the trunk due to the greater accumulation of dry mass. Therefore, the growth performance and wood characteristics analysis, indicated clonal materials superiority and, among these, CL2 was the one that showed the best silvicultural and energy performance. This finding corroborates studies by Nieri et al. (2018), who found the highest energy efficiency for CL2 in the Cerrado region of Southern Minas Gerais State. Eucalyptus urophylla $\mathrm{x}$ Eucalyptus camaldulensis recorded the highest volume yield, dry matter and stemwood biomass among seedlings material.

\section{CONCLUSIONS}

- $\quad$ Eucalyptus grandis x Eucalyptus urophylla clones performed better for energy production i due to their high volume yield, which was relevant in estimating biomass availability per tree and planted area.

- Growth, tree stem shape and basic density varied between and within the same genetic materials due to spacial planting arrangement. However, wood energy properties such as superior calorific value, ash content, fixed carbon and volatile matter remained stable.

\section{REFERENCES}

ASSOCIAÇÃO BRASILEIRA DE NORMAS TÉCNICAS. NBR 8633: carvão vegetal- determinação do poder calorífico. Rio de Janeiro, 1984.

ASSOCIAÇÃO BRASILEIRA DE NORMAS TÉCNICAS. NBR 11941-02: Determinação da densidade básica em madeira. Rio de Janeiro, 2003.

ANDRADE, T.C.G.R.; BARROS, N.F.; DIAS, L.E.; AZEVEDO, M.I.R. Biomass yield and calorific value of six clonal stands of Eucalyptus urophylla, S.T .Blake cultivated in the northeastern Brazil. Cerne, Lavras, v.19, n.3, p.467-472, 2013.

DIAS-FILHO, M.B.; FERREIRA, J.N. Barreiras a adoção de sistemas silvipastoris no Brasil. Belém:Embrapa Amazônia Oriental, Documentos n.347, 2008, 22 p.

EMPRESA BRASILEIRA DE PESQUISA AGROPECUÁRIA. Adoção da ILPF chega a 11,5 milhão de hectares. Disponível em:< https://www.embrapa.br/busca-de-noticias/-/noticia/17755008/adocao-de-ilpf-chega-a-115-milhoesde-hectares>. Acesso em: 02 mai. 2018.

FEDERAÇÃO DA AGRICULTURA E PECUÁRIA DO ESTADO DE MATOGROSSO (FAMATO). Diagnóstico de Florestas Plantadas do Estado de Mato Grosso. Cuiaba: Instituto Mato-Grossense de Economia Agropecuária (Imea), 2013. 106 p.

FINGER, C.A.G. Fundamentos de biometria florestal. Santa Maria: UFSM/FATEC,1992, 269 p.

FRANCHINI, J.C.; BALBINOT JUNIOR, A.A.; SICHIERI, F.R.; DEBIASI, H.; CONTE, O. Yield of soybean, pasture and wood in integrated crop livestock forest system in northwestern Paraná state, Brazil. Revista Ciência Agronômica, Fortaleza, v.45, n.5, p.1006-1013, 2014.

GIL, J.; SIEBOLD, M.; BERGER, T. Adoption and development of integrated crop-livestock-forestry systems in Mato Grosso, Brazil. Agriculture, Ecosystems and Environment, Amsterdã, v.199, p.394-406, 2015.

HENSKENS, F.L.; BATAGLLIA, M.; CHERRY, M.L.; BEADLE, C.L.Physiological basis of spacing effects on tree growth and for in Eucalyptus globulus. Trees, New York, v.15, p.367-377, 2001.
INSTITUTO
NACIONAL
DE METEREOLOGIA
2018.
Disponível
em:

<http://www.inmet.gov.br/portal/index.php?r=bdmep/bdmep>. Acesso em 15 jan. 2018.

FLORESTA, Curitiba, PR, v. 50, n. 4, p. 1707 - 1716, out/dez 2020.

Tonini, H. et.al.

ISSN eletrônico 1982-4688 
MACEDO, R.L.G.; VALE, A.B.; VENTURIN, N. Eucalipto em sistemas agroflorestais: Lavras, Editora da UFLA, 331 p. 2010

MARACAHIPES, L.; LENZA, E.; MARIMON, B.S.; OLIVEIRA, E.A.; PINTO, J.R.R.; MARIMON-JUNIOR, B. Estrutura e composição florística da vegetação lenhosa em cerrado rupestre na transição Cerrado-Floresta Amazônica, Mato Grosso, Brasil. Biota Neotrópica, campinas, v.11, n.1,p.1-9, 2011.

MINISTERIO DA AGRICULTURA PECUÁRIA E ABASTECIMENTO. Plano ABC-Agricultura de baixa emissão de carbono. Disponível em:< http://www.agricultura.gov.br/assuntos/sustentabilidade/plano-abc >. Acesso em: 12 mai. 2018.

NEVES, T.A.; PROTASIO, T.P.; TRUGILHO, P.F.; VALLE, M.L.A.; SOUSA, L.C.; VIEIRA, C.M.M. Qualidade da madeira de clones de Eucalyptus em diferentes idades para a produção de energia. Floresta e Ambiente, Seropédica, v.56, n.2, p.139-148, 2013.

NIERI, E.M.; MACEDO, R.L.G.; MARTINS, T.G.V.; MELO, L.A.; VENTURIN, R.P.; VENTURIN, N. Comportamento silvicultural de espécies florestais em arranjo para a integração pecuária floresta. Floresta, Curitiba, v.48, n.2, p.195-202, 2018.

OLIVEIRA, F.L.R.; CABACINHA, C.D.; SANTOS, L.D.T.; BARROSO, D.G.; SANTOS JUNIOR, A.; BRANT, M.C.; SAMPAIO, R.A. Crescimento inicial de eucalipto e acácia em diferentes arranjos de integração lavoura-pecuáriafloresta. Cerne, Lavras, v.21, p.227-233, 2015.

PEREIRA, B.L.C.; OLIVEIRA, A.C.; CARVALHO, A.M.M.L.; CARNEIRO, A.C.O.; VITAL, B.R.; SANTOS, L.C.Correlaçoes entre a relação Cerne/Alburno da madeira de eucalipto, rendimento e propriedades do carvão vegetal.Scientia Forestalis, Piracicaba, v.41, n.98, p.217-225, 2013.

REGAZZI. A.J.; SILVA, C.H.O. Teste para verificar a igualdade de parâmetros e a identidade de modelos de regressão não linear.I Dados no delineamento inteiramente casualizado. Revista Matemática e Estatística, São Paulo, v.22, n.3, p.33-45, 2004.

ROCHA. M.F.V.; VITAL. B.R.; CARNEIRO. A.C.O.; CARVALHO. A.M.M.L.; CARDOSO. M.T.; HEIN, P.R.G. Effects of plant spacing on the physical, chemical and energy properties of Eucalyptus wood and bark. Journal of Tropical Forest Science, New York, v.28, n.3, p.243-248, 2016.

SANTOS, L.C.; CARVALHO, A.M.M.L.; PEREIRA, B.L.C.; OLIVEIRA, A.C.; CARNEIRO, A.C.O.; TRUGILHO, P.F. Propriedades da madeira e estimativas de massa, carbono e energia de clones de Eucalyptus plantados em diferentes locais. Revista Árvore, Viçosa, v.36, n.5, p.971-980, 2012.

SEREGUETTI, G.C.; KLEBER PEREIRA LANÇAS.; SARTORI, M.S.; REZENDE, M.A.; SOLER, R.R. Efeito do espaçamento no crescimento e na densidade básica da madeira de Eucalyptus urophylla x Eucalyptus grandis em florestas de ciclo curto. Energia na Agricultura, Botucatu, v.30, n.3, p.257-262, 2015.

SOUZA, A.P.; MOTA, L.L.; ZAMADEL, T.; MARTIM, C.C.; ALMEIDA, F.T.; PAULINO, J.Classificação climática e balanço hídrico climatológico no estado de Mato Grosso. Nativa, Sinop, v.1, n.1, p.34-43, 2013.

TRUGILHO,P.F.densidade básica e estimativa de massa seca e lignina na madeira de espécies de Eucalyptus. Ciência e Agrotecnologia, Lavras, v.33, n.5, p.1228-1239, 2009.

VALE, A.T.; BRASIL, M.A.M.; LEÃO, A.L. Quantificação e caracterização energética da madeira e casca de espéci es do cerrado. Ciência Florestal, Santa Maria, v.12, n.1, p.71-80, 2002.

FLORESTA, Curitiba, PR, v. 50, n. 4, p. 1707 - 1716, out/dez 2020

Tonini, H. et.al.

ISSN eletrônico 1982-4688

DOI: 10.5380/rf.v50 i4. 59650 